\author{
Ismartaya ${ }^{1}$ \\ Safuan Safuan ${ }^{2}$ \\ Yulianingsih ${ }^{3}$ \\ Budiandru ${ }^{4}$ \\ Arief Ristia Pangestu ${ }^{5}$
}

\title{
THE INFLUENCE OF WORK MOTIVATION AND DISCIPLINE ON WORK ACHIEVEMENT THROUGH LEADERSHIP
}

\begin{abstract}
The purpose of this study is to determine whether there is an effect of motivation and work discipline on employee performance based on the leadership of the employees of PDAM Tita Pakuan Bogor City. The data collection technique used interviews and questionnaires, while the sampling technique used non-probability sampling with a sample size of 85 people. The results showed that motivation and work discipline had a positive and significant effect on employee performance through leadership. This can be seen from the results of simple linear regression analysis, multiple linear regression, $t$ test, coefficient of determination test, single test and path analysis. Leadership as an intervening variable mediates between motivation on employee work performance which is partially mediated and leadership as an intervening variable that mediates between motivations on employee work performance, both of which are full mediation.
\end{abstract}

Keywords: Work Motivation, Work Discipline, Leadership, Work Performance, Achievement.

\section{INTRODUCTION}

Bogor has had water service system since 1918. It was built by Dutch government. At that time, the name of drink Water Company was Gemeente Waterleiding Buitenzorg which utilized as the main water source within the production capacity of 70 liters per second. Furthermore, through the Decree of West Java Governor number HK. 011SK 1977, Bogor Municipal Waterworks began to be established. Furthermore, because the company began

${ }^{1}$ Dr Ismartaya, MM, Doctor of Management, Faculty of Economy, Djuanda University Bogor, Indonesia; e-mail: ismartaya@ unida.ac.id (corresponding author). ORCID: 0000-0003-0042-8632.

2 Dr Safuan, S.T., M.T., M.M, Post-graduate program Jayabaya University Jakarta, Indonesia; e-mail: safuan777@gmail.com. ORCID: 0000-0002-5865-5486.

${ }^{3}$ Yulianingsih, SE., MM, Faculty of Economy, Djuanda University Bogor, Indonesia; e-mail: yulianingsih@unida.ac.id ORCID: 0000-0001-9760-2224.

4 Dr Budiandru, SE., Ak., ME.Sy., CA., CPA, University of Muhammadiyah Prof. Dr. Hamka, Indonesia; e-mail: budiandru@uhamka.ac.id. ORCID: 0000-0002-4915-2908.

5 Arief Ristia Pangestu, S. Ked, Student of Medicine, Faculty of Medicine, Lampung University, Indonesia; e-mail: arief.pangestuu@ gmail.com. ORCID: 0000-0003-3096-1315. 
to develop, Bogor governor issued a mayor's decree number 011.45-75/2002 regarding the designation of Bogor Municipal Waterworks new logo and the addition of the name Tirta Pakuan, thus, the name of Bogor Municipal Waterworks changed to Tirta Pakuan Bogor Municipal Waterworks. Tirta Pakuan Bogor Municipal Waterworks tried to improve social services that related to the company's vision, mission and goals. One of them is the implementation of management through computerized information system, an integrated network that is capable to carry out all session of monitoring and automating customer administration and billing data quickly and precisely.

The current technological developments have the big impacton the Company, especially Tirta Pakuan Bogor Municipal Waterworks regarding the information access. National and international network facilities are rapidly growing (Safuan, 2019). The conditions described above imply a demand for adequate human resource support. Since, no matter how sophisticated the technology is, if there is no support from reliable human resources, it will not obtain any better result. Human resources in a company should have high work discipline, motivation, performance and qualified leadership qualities because these are the main points that will determine the success of a company (Hengky, 2013).

The leader of an organization has a position among his subordinates, thus, it will help to provide guidance, instruction, advice and correction if needed (Sondang, 2009). Motivation is the desire inside an individual that stimulates them to take any action (Winardi, 2000).

Daft stated that motivation was a strength that came from inside or outside a person and generated enthusiasm and persistence to achieve something. Work motivation will affect productivity and a manager's job is to distribute work motivation to achieve organizational goals (Daft, 2010).

Hasibuan (2011) interprets that discipline happens when employees always come to work and off work on time. That opinion is one of organizational demands. Therefore, discipline can be interpreted as either written or unwritten behavior. Discipline is a method used by leaders to communicate with employees, therefore the employee is willing to change behavior as an effort to increase an individual awareness and willingness to obey all applicable organizational rules and social norms. (Rivai et al., 2013).

Sastro Hadiwirja (2012) declares that discipline is an attitude of respect, obedience and obligation to the regulations, both written and unwritten and able to carry out, and accept the sanctions if they break the rules of duties and authorities. In leadership there is a relationship among humans, the relationship affecting 12 leaders and the obedience relationship of followers because influenced by leader's authority. Followers are affected by the power of the leader, and a sense of obedience spontaneously arises to the leader (Kartono, 2016). Robbins has stated that (inside Wen, Theresa, Kelana, Othman \& Syed, 2019) leadership is an ability to influence a group to achieve a goal. This opinion indicates all group/organization member as unity, therefore leadership can be defined as the ability to influence all members of an organization to be willing to carry out activities to achieve organizational goals.

While work achievement, Mangkunegara (2015) stated that work achievement is the result of job implementation, whether physical/material or non-physical/non-material. In carrying out his duties as stated in Job Description, every worker's results need to be assessed after a certain period. The term of work achievement comes from the word Actual Performance (an actual work achievement or an achievement achieved by someone). The definition of work performance is the quality and quantity of work achieved by an employee 
to carry out their duties related to the responsibilities assigned (Nawawi, 2013). Hasibuan (2011) stated that work achievement is a result of work achieved by a person in carrying out the tasks assigned to them based on skill, sincerity and time.

Leadership is a key element in a success (or a failure) of most organizations due to the vital role of leaders in providing the necessary guidance to help the organization achieve its goals. Defense-economic businesses, as well as other leading civil-economic business, need to have talented and creative managers in order to be successful in the $21^{\text {st }}$ century. One of the most important criteria to select effective managers is competence (Van Hoang et al., 2020). Leadership in the organization needs to be owned by all internal members of the organization, regardless of its vision and mission. Therefore, an organization or a company needs a leader figure that can be an example for other internal members of the organization (Paais, 2020).

The attention and trust of organizational members in this study were measured by green self-efficacy, as well as green awareness. The social identity theory of leadership in this research shows that there are external factors outside the leadership that influence support for environmental policies (Kardoyo, Feriady, Farliana, Nurkhim, 2020). Other studies conducted by (Siswanti, 2020) confirm the impact of empowering leadership on psychological empowerment, and the influence of empowering leadership on individual creativity. It is also said that there is the influence of psychological empowerment on individual creativity, and the impact of empowering leadership on individual creativity is mediated by psychological empowerment. This research neglects another type of leadership.

Based on the explanation above, the researchers tried to examine Tirta Pakuan Bogor Municipal Waterworks which is related to the work motivation and work discipline toward employee performance through Leadership as Intervening variable. This study aims to determine whether there is an effect of motivation and work discipline on employee performance based on the leadership system Tirta Pakuan Bogor Municipal Waterworks.

\section{Research Hypothesis}

The hypothesis model used in this research is explained as below:

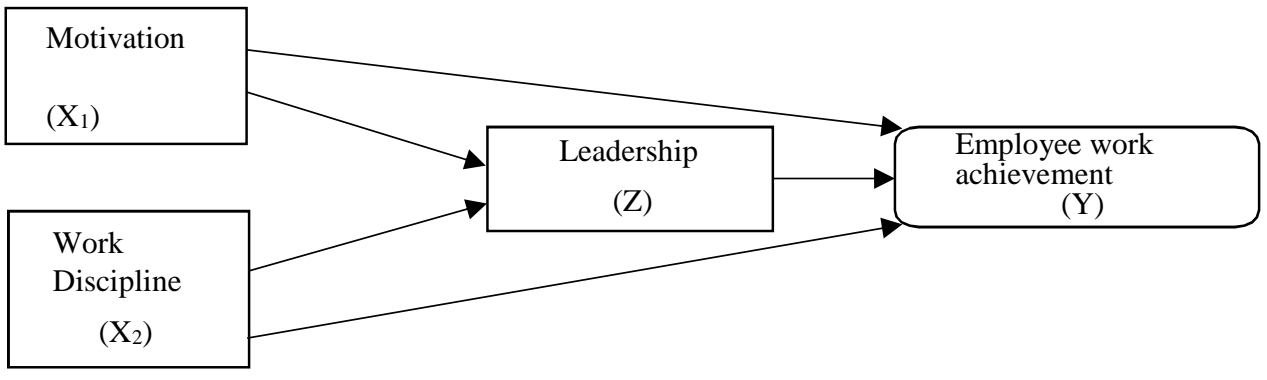

Fig. 1. Research Model

Source: own study. 
The Hypotheses explained as below:

H1: there is the influence between motivations on employee achievement;

H2: there is the influence between motivations on leadership;

H3: there is the influence between work disciplines on employee achievement;

H4: there is the influence between work disciplines on leadership;

H5: there is the influence between employee leadership as an intervening variable on Employee Achievement;

H6: there is the influence of motivation on work performance through employee leadership; H7: there is an effect of work discipline on employee achievement through leadership.

\section{METHODOLOGY}

The type of research applied in this study is explanatory, which aims to explain the relationship between a variable and another, which is used to test the results hypothesis of pre-existing research. The population of this study were the employees at Tirta Pakuan Bogor Municipal Waterworks, West Java Province. The number of samples in this study were 85 respondents from 200 employees in total work. The sampling technique used was a saturated sample, the technique of determining the sample by having every population. The measurement scale used Likert scale, and the instruments used questionnaires and interviews. This research uses qualitative and quantitative analysis techniques. The quantitative analysis uses SPSS program, by testing the validity and reliability test, then the correlation coefficient, simple linear regression test to determine the effect and direction of each independent variable $(\mathrm{X})$ toward dependent variable $(\mathrm{Y})$ and intervening variable $(\mathrm{Z})$, then test coefficient determination, $t$ test was done to observe how far the influence of independent variable individually explaining dependent variable, then multiple linear regression to find out the dependent variable (Y).

If two or more independent variables (X) are fluctuated, the Sobel test is used to find out whether the relationship through mediating variable is significantly capable as mediator of relationship. Thus, the researchers tried to use single test to find out how far the mediation of intervention variable $(\mathrm{Z})$ could affect dependent variable $(\mathrm{Y})$. The Sobel test used $\mathrm{z}$ test by the formula explained as below:

$$
z=\frac{a b}{\sqrt[\square]{\left(b^{2} S E_{a}^{2}\right)+\left(a^{2} S E_{b}^{2}\right)}}
$$

\section{Information:}

$a=$ Regression coefficient of independent variable on mediating variable.

$b=$ Regression coefficient of mediating variable on dependent variable.

$S E_{a}=$ standard error of estimation from the influence of independent variable on mediating variable.

$S E_{b}=$ standard error of estimation on the effect of mediating variable on dependent variable.

\section{RESULT AND DISCUSSION}

To obtain the results of the study, there are several data analyzes including: correlation coefficient test, simple linear regression test, coefficient of determination, multiple linear 
regression test and significance test. Based on the results of tests carried out at Tirta Pakuan Bogor Municipal Waterworks, the results were obtained as below:

Table 1. Analysis Result

\begin{tabular}{|c|l|c|c|c|c|}
\hline No. & \multicolumn{1}{|c|}{ Variable } & Correlation & Determination & t/F count & $\begin{array}{c}\text { Hypothesis } \\
\text { result }\end{array}$ \\
\hline 1 & $\begin{array}{l}\text { Work motivation Toward } \\
\text { Employee Achievement }\end{array}$ & 0,685 & $46,7 \%$ & 8,989 & $\begin{array}{c}\text { Hypothesis } \\
\text { Accepted }\end{array}$ \\
\hline 2 & $\begin{array}{l}\text { Work Motivation toward } \\
\text { Leadership }\end{array}$ & 0,518 & $27,3 \%$ & 5,837 & $\begin{array}{c}\text { Hypothesis } \\
\text { Accepted }\end{array}$ \\
\hline 3 & $\begin{array}{l}\text { Work Discipline toward } \\
\text { Employee Achievement }\end{array}$ & 0,294 & $8,71 \%$ & 2,940 & $\begin{array}{c}\text { Hypothesis } \\
\text { Accepted }\end{array}$ \\
\hline 4 & $\begin{array}{l}\text { Work Discipline toward } \\
\text { Leadership }\end{array}$ & 0,407 & $16,65 \%$ & 4,284 & $\begin{array}{c}\text { Hypothesis } \\
\text { Accepted }\end{array}$ \\
\hline 5 & $\begin{array}{l}\text { Work Leadership toward } \\
\text { Employee Achievement }\end{array}$ & 0,630 & $39,20 \%$ & 7,682 & $\begin{array}{c}\text { Hypothesis } \\
\text { Accepted }\end{array}$ \\
\hline 6 & $\begin{array}{l}\text { Work Motivation toward } \\
\text { Employee Performance } \\
\text { Achievement through } \\
\text { Leadership }\end{array}$ & 0,754 & $56,72 \%$ & 3,573 & $\begin{array}{c}\text { Hypothesis } \\
\text { Accepted }\end{array}$ \\
\hline 7 & $\begin{array}{l}\text { Work Discipline on } \\
\text { Employee Achievement } \\
\text { through Leadership }\end{array}$ & 0,627 & $39,23 \%$ & 3,601 & $\begin{array}{c}\text { Hypothesis } \\
\text { Accepted }\end{array}$ \\
\hline
\end{tabular}

Source: own study.

Based on Table 1, it can be seen that the results of $t$ test (partial significance test) and the Sobel test (simultaneous or joint significance test) consist the result as below:

1. Work motivation has the influence on employee work achievement which the t count $(8.989)>t$ Table (1.986) thus the hypothesis is accepted.

2. Work motivation has the influence on leadership, which the value of $t$ count $(5.837)>$ t Table (1.986) thus the hypothesis is accepted.

3. Work discipline has the influence on employee work achievement which the value of t count $(2,940)>t$ Table (1.986) thus the hypothesis is accepted.

4. Work discipline has the influence on leadership which the value of $t$ count (4.284) > t Table (1.986).

5. Work leadership has the influence on employee achievement which the value of $\mathrm{t}$ count $(7,682)>\mathrm{t}$ table (1.986) thus the hypothesis is accepted.

6. Work Motivation has the influence on Employee Achievement through Leadership which the value of $t$ count (3.573) $>t$ Table (1.986) thus the hypothesis is accepted.

7. Work Discipline has the influence on Employee Achievement through Leadership which the value of $t$ count (3.601) > t Table (1.986) therefore the hypothesis is accepted.

The variables were tested using regression test to see whether there is the influence of each independent variables against dependent variables or not by comparing the p-value. If the p-value is smaller than 0.05 then Ha is accepted and Ho is rejected and vice versa. 
Table 2. Results of Motivation Regression Test on Employee Performance

Coefficients $^{\mathrm{a}}$

\begin{tabular}{|c|c|c|c|c|c|}
\hline \multirow{2}{*}{ Model } & \multicolumn{2}{|c|}{ Unstandardized Coefficients } & Standardized & \multirow{2}{*}{$\mathrm{t}$} & \multirow{2}{*}{ Sig. } \\
\hline & B & Std. Error & Beta & & \\
\hline $\begin{array}{l}\text { 1. (Constant) } \\
\text { Total X1 }\end{array}$ & 3.046 & 1.613 & 0.682 & $\begin{array}{|ll|}1.888 & \\
& 8.990\end{array}$ & .063 \\
\hline
\end{tabular}

a. Dependent Variable: total.

Based on Table 2, it can be seen that the regression coefficient value of Motivation variable is positive with the total of 0.812 . This shows that the motivation variable has a positive relationship on employee work achievement, where it can be said that the better work motivation the better employee achievement level.

The Influence of Motivation Variables on Employee Work Performance Variables, Based on data analysis and hypothesis testing carried out in this study, the following result was obtained: Work motivation has the influence on employee work achievement which the $\mathrm{t}$ count $(8.989)>\mathrm{t}$ Table (1.986) thus the hypothesis is accepted. It is known that coefficient regression value for Motivation variable has a positive value of 0.812 . This indicated that the motivation variable has a positive relationship on employee work achievement, where it can be said that the better work motivation the better employee achievement level.

Table 3. The Results of Work Motivation Regression toward Leadership

\section{Coefficients $^{\mathbf{a}}$}

\begin{tabular}{|c|c|c|c|c|c|}
\hline \multirow{2}{*}{ Model } & \multicolumn{2}{|c|}{ Unstandardized Coefficients } & $\begin{array}{l}\text { Standarded } \\
\text { Coefficients }\end{array}$ & \multirow{2}{*}{$\mathrm{T}$} & \multirow{2}{*}{ Sig. } \\
\hline & B & Std. Error & Beta & & \\
\hline $\begin{array}{l}\text { 1. (Constant) } \\
\text { TotalX1 }\end{array}$ & 6.698 & 1.383 & .519 & $\begin{array}{r}4.848 \\
5.831\end{array}$ & .000 \\
\hline
\end{tabular}

a. Dependent Variable: total Z.

Based on Table 3, it can be seen that the regression coefficient value of motivation variable is positive at 0.450 . It is indicated that the motivation variable has a positive relationship with leadership, which can be said that the better work motivation, the higher leadership level.

The Influence of Motivation variable toward leadership, based on the data analysis and hypothesis test of this research, it is known that: Work motivation has the influence on leadership, which the value of $t$ count $(5.837)>t$ Table (1.986) thus the hypothesis is accepted, it can be seen that the regression coefficient value of motivation variable is positive at 0.450 . It is indicated that the motivation variable has positive relationship with leadership, which can be said that the better work motivation, the higher leadership level. 
Table 4. The Results of Work Discipline Regression Test on Employee Achievement

\begin{tabular}{|c|c|c|c|c|c|}
\hline \multicolumn{6}{|c|}{ Coefficients $^{\mathrm{a}}$} \\
\hline \multirow{2}{*}{ Model } & \multicolumn{2}{|c|}{ Unstandardized Coefficients } & $\begin{array}{l}\text { Standardized } \\
\text { Coefficients }\end{array}$ & \multirow{2}{*}{$\mathrm{T}$} & \multirow{2}{*}{ Sig. } \\
\hline & $\mathrm{B}$ & Std. Error & Beta & & \\
\hline $\begin{array}{l}\text { 1. (Constant) } \\
\text { Total X2 }\end{array}$ & 11.726 & \begin{tabular}{|ll}
1.941 & \\
& .12
\end{tabular} & .294 & $\begin{array}{r}6.043 \\
2.937\end{array}$ & .000 \\
\hline
\end{tabular}

a. Dependent Variable: total.

Based on Table 4, it can be seen that regression coefficient value of work discipline variable is positive at 0.374 . This indicated that work discipline variable has positive relationship with employee work achievement, which can be said that the better work discipline, the better level of employee achievement.

The Influence of work discipline toward variable of work achievement, based on the data analysis and hypothesis test it is known that: Work discipline has an influence on employee work achievement which the value of $t$ count $(2,940)>t$ Table (1.986) thus the hypothesis is accepted. It can be seen that regression coefficient value of work discipline variable is positive at 0.374 . This indicated that work discipline variable has a positive relationships with employee work achievement, which can be said that the better work discipline, the better level of employee achievement.

Table 5. Results of the Work Discipline Regression Test on Leadership

\section{Coefficients $^{\mathbf{a}}$}

\begin{tabular}{|c|c|c|c|c|c|}
\hline \multirow{2}{*}{ Model } & \multicolumn{2}{|c|}{ Unstandardized Coefficients } & Standardized & & \\
\hline & B & Std. Error & Beta & & \\
\hline $\begin{array}{l}\text { 1. (Constant) } \\
\text { Total X2 }\end{array}$ & \begin{tabular}{ll|}
8.938 & \\
& .379 \\
\end{tabular} & 1.353 & .406 & $\begin{array}{r}6.598 \\
4.282\end{array}$ & .000 \\
\hline
\end{tabular}

a. Dependent Variable: total Z.

Based on Table 5, it can be seen that regression coefficient value for work discipline variable has a positive value of 0.379 . This indicates that work discipline variable hasa positive relationship with leadership, where it can be said that the better work discipline, the higher and the level of leadership.

The influence of work discipline variable toward leadership, based on the data analysis and hypothesis test it is known that: Work discipline has the influence on leadership which the value of t count (4.284) $>t$ Table (1.986). It can be seen that regression coefficient value for work discipline variable has a positive value of 0.379 . This indicates that work discipline variable has positive relationship with leadership, where it can be said that the better work discipline, so, the higher level of leadership.

Based on Table 6, it can be seen that coefficient regression value for leadership variable has a positive value of 0.887 . This shows that leadership variable has a positive relationship with employee work achievement, which can be said that the higher leadership level, the better employee's work achievement level. 
Table 6 Leadership Regression Test Results on Employee Achievement

\begin{tabular}{|c|c|c|c|c|c|}
\hline \multicolumn{6}{|c|}{ Coefficients $^{\mathrm{a}}$} \\
\hline \multirow[t]{2}{*}{ Model } & \multicolumn{2}{|c|}{ Unstandardized Coefficients } & $\begin{array}{l}\text { Standardized } \\
\text { Coefficients }\end{array}$ & \multirow[t]{2}{*}{$\mathrm{T}$} & \multirow[t]{2}{*}{ Sig. } \\
\hline & $\mathrm{B}$ & Std. Error & Beta & & \\
\hline 1. (Constant) & 4.812 & 1.657 & & 2.902 & .006 \\
\hline Total Z & .887 & .112 & .626 & 7.678 & .000 \\
\hline
\end{tabular}

a. Dependent Variable: total.

The influence of leadership variable toward the variable of work achievement, based on the data analysis and hypothesis test it is known that: Work leadership has the influence on employee achievement which the value of $t$ count $(7,682)>t$ table (1.986) thus the hypothesis is accepted. It can be seen that coefficient regression value for leadership variable has a positive value of 0.887 . The leadership variable has a positive relationship with employee work achievement, it can be concluded that the higher leadership level, so, the better employee's work achievement level.

Based on the data analysis and hypothesis test carried out in this study, it can be known that the work motivation has the influence on employee achievement through leadership which the $t$ value (3.573) > t Table (1.986) thus the hypothesis is accepted. The influence of work discipline variables on work achievement variables. While, the work discipline has the influence on employee performance through leadership where the value of $\mathrm{t}$ count (3.601)> t Table (1.986) thus, the hypothesis be accepted.

\section{CONCLUSION}

Therefore, it can be concluded that the employee performance is influenced by the motivation and work discipline of the employee. The employee's motivation and discipline indicated that they had passion on their job. It showed that they loved their job. This makes their performance in work become better. However, if their motivation and work discipline are low, then their work performance will be decreased.

\section{REFERENCES}

Hasibuan, P. S. M. (2015). Manajemen Sumber Daya Manusia. PT. Bumi Aksara.

Hengky, S. H. (2013). Fundamentals of Human Resource Management. „Journal of Human Resources Management and Labor Studies". DOI: 0470169680.

Kardoyo K., Muhammad F., Farliana, N., Nurkhin, A. (2020). Influence of the Green Leadership Toward Environmental Policies Support. „Journal of Asian Finance, Economics and Business", 7(11), 459-467.

Kartono, K. (2016). Pemimpin dan Kepemimpinan, Apakah Kepemimpinan Abnormal Itu? Rajawali Pers.

Maartje Paais, J. R. P. (2020). Effect of Motivation, Leadership, and Organizational Culture on Satisfaction and Employee Performance. „Journal of Asian Finance, Economics and Business", 7(8), 577-588.

Mangkunegara, A. P. (2015). Company Resource Management (PT Teens Rosdakarya (ed.)). 
Nawawi. (2013). Budaya Organisasi Kepemimpinan dan Kinerja. Nawawi (2013:244) Yang Berjudul Budaya Organisasi Kepemimpinan Dan Kinerja.

Daft, R. L. (2010). Era baru manajemen [in:] Era baru manajemen.

Rivai, V., Bachtiar, Amar, B. R. (2013). Pemimpin Dan Kepemimpinan Dalam Organisasi. Raja Grafindo Persada.

Safuan, I. (2019). Manajemen Sumber Daya Manusia. Penerbit Alfabeta.

Sastrohadiwiryo, S. (2012). Manajemen Tenaga Kerja Indonesia, Pendekatan Administratif dan Operasional. Penerbit Bumi Aksara.

Sondang, P. S. (2009). Organisasi, kepemimpinan dan Perilaku administrasi. Jakarta: Gunung Agung.

Van Hoang, C., Nguyen, N. H., Nguyen, L. Q. T., Tran, M. D. (2020). Determinants of middle managers' leadership in the Vietnamese economic-defense enterprises. „Journal of Asian Finance, Economics and Business" No. 8.543, Vol. 7. DOI: 10.13106/JAFEB.2020.

Wen, T. B., Theresa, C. F. H., Kelana, B. W. Y., Othman, R., \& Syed, O. R. (2019). Leadership Styles in Influencing Employees' Job Performances. „International Journal of Academic Research in Business and Social Sciences", 9(9). DOI: 10.6007/IJARBSS/v9-i9/6269

Winardi. (2000). Kepemimpinan dalam manajemen. Rineka Cipta.

Yuni Siswanti, M. M. (2020). Empowering Leadership and Individual Creativity: The Mediation Role of Psychological Empowerment in Facing Covid-19 Pandemic. „Journal of Asian Finance, Economics and Business", 7(11), 809-816.

DOI: 10.7862/rz.2021.mmr.02

The text was submitted to the editorial office: January 2021.

The text was accepted for publication: March 2021. 
